Arab Univ. J. Agric. Sci., Ain Shams Univ., Cairo, 14(2), 803-812, 2006

\title{
SOME PHYSIOLOGICAL AND HISTOPATHOLOGICAL EFFECTS OF TWO PESTICIDES AGAINST THE COTTON LEAF WORM, SPODOPTERA LITTORALIS (BOISD.)
}

\section{[51]}

\author{
Youssef $^{1}$, L.A.
}

\begin{abstract}
The toxicological effect of two pesticides, pyriproxyfen and abamectin were evaluated on third instar larvae of the cotton leafworm, Spodoptera littoralis (Boisd.). According to the estimated toxicity values, i.e. $\mathrm{LC}_{50}, \mathrm{LC}_{90}$ and slope values, the chemical abamectin showed that it was slightly more toxic than pyriproxyfen. The effect of these two insecticides, at the determined $\mathrm{LC}_{50}$ and $\mathrm{LC}_{25}$ values on the digestive physiology of treated larvae, as indicated by some nutritional indices was conducted. Obtained results demonstrated that pyriproxyfen and abamectin caused a significance reduction in growth of treated larvae as depicted by larval weight gain Also, a significant decrease was found in the efficiency of ingested food to body matter and efficiency of conversion of digested food to body matter as compared to untreated insects. These effects were generally more evident when abemectin was used. The two tested compound also caused histological changes in the midgut of treated larvae, in form of disruption in the columnar epithelium cells and stretching leading to tearing in the peritrophic membrane. This observation might explain the impairment in nutritional indices in treated larvae as compared to the control.
\end{abstract}

Keywords: Cotton leafworm, Abamectin, Pyriproxyfen, Digestive indices, Midgut histology

\section{INTRODUCTION}

The cotton leafworm, Spodoptera littoralis (Boisd.) is considered the most serious pest infesting the Egyptian cotton plant. This insect also attacks other economically important crops such as; cucumber, potato, okra, egg plants and oth- ers. In the past decade, the potency of different novel insecticides were used for the control of $S$. littoralis, e.g. benzoyl phenyl urea (chitin synthesis inhibitors), juvenile hormone mimics (hormones balance disrupters) and microorganism's fermentation derived compounds. Such agents have been looked at as selective

1- Plant Protection Dept., Fac. Agric. Ain Shams Univ. Shoubra El-Kheima, Cairo, Egypt.

(Received May 27, 2006)

(Accepted May 30, 2006) 
agents to suppress both growth and development of larvae. Since then, several studies have been directed to elucidate the biochemical effects of such chemicals. For example, it was found that diflubenzuron, pyriproxyfen and abamectin caused a significant alteration of different enzymatic activities, i.e. estarase, chitinase and penoloxidase (Mostafa, 1993; Farag, 2001, Raymond-Delpech et al 2005). The literature cited on these compounds suggested their potential successful use as alternatives to classical insecticides. Furthermore such chemicals exhibit a relative short environmental persistence, low mammalian toxicity as well as the ease of their formulated application (Quistad et al 1974; Halley et al 1993; Dhadialla et al 1998).

The aim of the present study was to evaluate the toxicity of two insecticides pyriproxyfen and abamectin on a susceptible strain of the cotton leafworm Spodoptera littorallis. Also, the effect of these chemicals on nutritional indices of treated larvae was determined, as well, as their effect on the histological structure of the midgut.

\section{MATERIAL AND METHODS}

\section{1- Biopesticides used}

1-1- Pyriproxyfen: $\operatorname{Admiral}^{\circledR}(10 \% \mathrm{EC})$, is a juvenile hormone mimic (JHM), 4phenoxyphenyl (RS)-2-(2-pyridyloxy) propyl ether. It was obtained from Sumitomo Chemical Co. (Osaka, Japan).

2-2- Abamectin: $\operatorname{Vertimec}^{\circledR}(1.8 \%$ EC), belongs to the avermectins group (a microbial insecticides and acaricides) containing more than $80 \%$ avermectin $\mathrm{B} 1 \mathrm{a}$ and less than $20 \%$ avermectin B1b. This compound was obtained from Syngenta Agrochemical Co. (Qualiobia Governorate, Egypt).

\section{2- Insect rearing technique}

The experiments of the present work were carried out under laboratory conditions of $27 \pm 2{ }^{\circ} \mathrm{C}$ and $65 \pm 5 \%$ R.H. The cotton leafworm, S.littoralis susceptible strain was obtained as egg-masses from Syngenta Agrochemical Co. (Qualiobia Governorate, Egypt). Each egg-mass was separately confined in sterilized jars, tapped with muslin covers. Upon larval hatching, fresh and clean castor-bean leaves were provided daily as food and clean jars were substituted for the used ones. At pupation, the pupae were sexed and then confined, in jars, at a sex ratio of 2 females to one male, until moth emergence. Upon adult emergence, moths were placed in glass globes and supplied with a cotton wick immersed in a $10 \%$ sugar solution as a source of food. In addition two leaves of Nerium oleander were provided as an oviposition site. Deposited egg-masses were daily collected for further experiment.

\section{3- Establishing toxicity lines}

An emulsifiable formulation of each tested biopesticide was prepared in water as a stock solution and a series of six concentrations for each chemical were prepared from this solution, Clean castor bean leaves were sprayed with one of the prepared concentrations of each compound at rate of $0.7 \mathrm{ml} / 150 \mathrm{~cm}^{2}$, the leaves were left to dry at room temperature.

Ten newly molted $3^{\text {rd }}$ instar larvae, each with an average weight of $80 \mathrm{mg}$, 
were placed in plastic cup measuring 20 $\mathrm{cm}$ diameter and provided with treated leaves with one of the prepared concentrations. The larvae were fed on treated castor bean leaves for two days and then offered untreated leaves. As a control, a similar number of larvae were provided with untreated castor bean leaves. Each concentration was replicated ten times. Mortality counts were assessed and corrected according to the formula of $\mathbf{A b}$ bott (1925). Concentration mortality regression lines were carried out according to the method of Finney (1972) and the $\mathrm{LC}_{25}, \mathrm{LC}_{50}$ and $\mathrm{LC}_{90}$ values determined.

\section{4- Physiological Parameters}

The digestive physiology as indicated by the calculation of nutritional indices were determined for third instar larvae treated with pyriproxyfen and abamectin at the determined $\mathrm{LC}_{25}$ and $\mathrm{LC}_{50}$ values, as well as their equivalent control.

For each treatment, 100 newly ecdysed (0-6 hours) $3^{\text {rd }}$ instar larvae were placed in large plastic dishes. The initial fresh weight of larvae was determined before being offered a recorded weight of castor oil bean leaves treated with the calculated $\mathrm{LC}_{25}$ or $\mathrm{LC}_{50}$ of each of pyriproxyfen or abamectin for 48 hours. Larvae were then offered untreated leaves for the remaining duration of the larval stage. A control was set comprising an equivalent number of insects which were offered at all times untreated leaves.

The weights of larvae, the daily offered fresh castor oil leaves, faeces and unconsumed leaves of the previous day were recorded on a daily bases. The amount of diet eaten was estimated by the difference in dry weight of the diet before and after testing. From these records the following nutritional indices were considered after 24, 72, 120, 168 and 240 hours following treatment, according to the method described by Mcfarlane (1985) and using the equations set by Waldauer (1968).

(1) Larval weight gain or loss.

(2) Amount of ingested food.

(3) Amount of digested food.

(4) Approximate digestibility (AD).

(5) Efficiency of conversion of ingested food (ECI) to body matter.

(6) Efficiency of conversion of digested food (ECD) to body matter.

\section{5- Histological study}

To clarify the results of the nutritional indices in larvae treated with $\mathrm{LC}_{50}$ of either pyriproxyfen or abamectin, a histological study of the midgut was conducted. On the third day following treatment, 5 larvae from each treatment as well as from the untreated group were picked out and dissected. Their mid-guts were fixed in aqueous Bouin's solution, then dehydrated in ethanol solutions and cleared in xylene and then embedded in paraffin. Specimen were then cut at $6 \square$ thickness and then stained by Ehrlich's haematoxylin and counter stained by eo$\sin$.

\section{6- Statistical analysis}

Results were analyzed statistically using the Analysis of Variance (ANOVA) by the computer program (Sigma Plot version 2.0 for Windows) at a single time point which was examined by use of twotailed student $t$ test.

\section{RESULTS}




\section{1- Toxicity values of pyriproxyfen and abamectin on S. littorallis larvae}

According to toxicity regression lines (Fig. 1), both tested compounds exhibited an insecticidal activity to third instar larvae of $S$. littoralis (Table 1). Abamectin showed a higher toxic activity as expressed by the determined $\mathrm{LC}_{50}$ and $\mathrm{LC}_{90}$, i.e. 69.11 and $\mathrm{LC}_{90} 239.11 \mathrm{ppm}$, respectively. Pyriproxyfen gave a higher values of $\mathrm{LC}_{50} 85.11$ and $\mathrm{LC}_{90} 580.00 \mathrm{ppm}$. Both toxicity index and relative potency values based on the determined $\mathrm{LC}_{50}$ were $81.28,1.23$ for pyriproxyfen, 100.00 and 1.00 for abamectin, respectively. Also, the values of $\mathrm{LC}_{90} / \mathrm{LC}_{50}$ ratio were 6.82 and 3.46 for pyriproxyfen and abamectin, respectively. The $\mathrm{LC}_{25}$ for these two respective mentioned chemicals was 42.5 and $23.91 \mathrm{ppm}$.

In addition, the slope value of abamectin was 2.38 higher than that of pyriproxyfen i.e. 1.58 (Table 1). Such difference in the slope values may be due to the slow action of pyriproxyfen compared to the relatively rapid action of abamectin (Figure 1).

\section{2- Effect of pyriproxyfen and abamec- tin on nutritional indices}

As shown in Figure 2, the larval growth factor as estimated by larval body weight gain post treatment was significantly affected in larvae treated with the two tested insecticides. Pyriproxyfen at its $\mathrm{LC}_{50}$ value of $85.11 \mathrm{ppm}$ caused a lower weight gain in treated larvae by nearly $73,72,70,48$ and $30 \%$ than their control, after 24, 72, 120, 168 and 240 hours, respectively. When $\mathrm{LC}_{25}$ (i.e. $42.50 \mathrm{ppm}$ ) of this chemical was tested, the weight decrease in treated larvae than control larvae was 59, 62, 56, 57 and 46 $\%$ to the respective times mentioned. Abamectin caused a significantly higher reduction in larval weight than their equivalent control which was less by 45 , 43,36 and $25 \%$ when $\mathrm{LC}_{50}(69.18 \mathrm{ppm})$ was tested and by $88,85,55,55$ and $52 \%$ when $\mathrm{LC}_{25}(239.11 \mathrm{ppm})$ was used after the intervals of 24, 72, 120, 168 and 240 hours following treatment, respectively, (Table 2).

The ingested food parameter in larvae fed on castor oil leaves treated with either $\mathrm{LC}_{25}$ of pyriproxyfen or with both tested LC's of abamectin was half that of their equivalent control, (i.e. 50\%). Meanwhile, it was only slightly higher reaching $62.5 \%$ with $\mathrm{LC}_{50}$ of pyriproxyfen,. The amount of digested food was also lowered by 60 and $40 \%$ than the control, as a result of treatment with $\mathrm{LC}_{50}$ values of pyriproxyfen and abamectin, respectively. However, it was $80 \%$ for both chemicals at $\mathrm{LC}_{25}$ values. The weight of unconsumed treated leaves by larvae was nonsignificantly higher reaching 108.33 and $101.66 \%$ after treatment with $\mathrm{LC}_{50}$ and $\mathrm{LC}_{25}$ of pyriproxyfen. Meanwhile, a significant $256.66 \%$ increase in unconsumed leaves was found after treatment with LC $_{50}$ of abamectin (Fig. 2).

\section{3- Histological effect:}

The histological structure of the midgut in S. littorallis larvae show that it is lined by the peritrophic membrane which envelops the food particles followed by a closely arranged columnar epithelial layer with a rather broad apex, bearing a microvillus border. Also, observed are small goblet cells and both types of cells rest on 


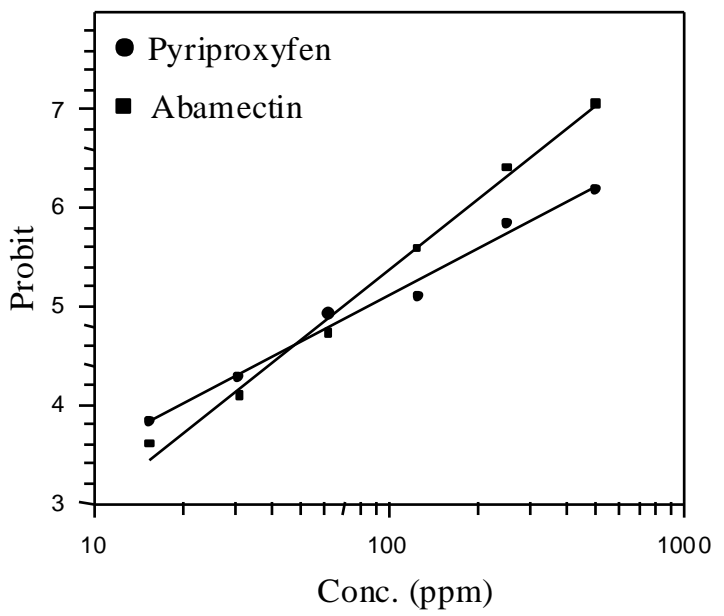

Fig. 1. Toxicity regression lines of pyriproxyfen and abamectin against third instar larvae of the cotton leafworm, Spodoptera littoralis (Boisd.)

Table 1. Toxicity values of pyriproxifen and abamectin on the third instar larvae of Spodoptera littoralis

\begin{tabular}{|ccccccc|}
\hline Compound & $\begin{array}{c}\mathrm{LC}_{50} \\
(\mathrm{ppm})\end{array}$ & $\begin{array}{c}\mathrm{LC}_{90} \\
(\mathrm{ppm})\end{array}$ & Slope & $\begin{array}{c}\text { Toxicity } \\
\text { index }(\mathrm{Ti}) \\
\text { based on } \\
\mathrm{LC}_{50}\end{array}$ & $\begin{array}{c}\text { Relative } \\
\text { potency } \\
\text { based on } \\
\mathrm{LC}_{50}\end{array}$ & $\begin{array}{c}\mathrm{LC}_{90} / \mathrm{LC}_{50} \\
\text { ratio }\end{array}$ \\
\hline Pyriproxyfen & 85.11 & 580.00 & 1.58 & 81.28 & 1.23 & 6.82 \\
Abamectin & 69.18 & 239.11 & 2.38 & 100.0. & 1.00 & 3.46 \\
\hline
\end{tabular}




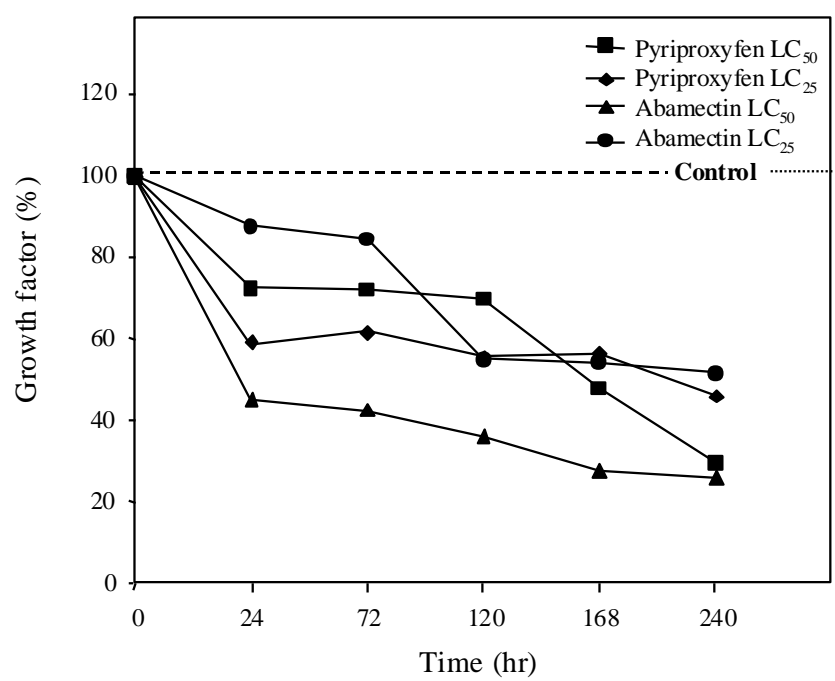

Fig. 2. Effects of pyriproxyfen and abamectin at $\mathrm{LC}_{50}$ and $\mathrm{LC}_{25}$ values on larval weights of third instar larvae of Spodoptera littoralis (Boisd.)

Table 2. Effect of pyriproxyfen and abamectin on nutriotional indices of third instar larvae of the cotton leafworm, Spodoptera littoralis (Boisd.)

\begin{tabular}{|lccccc|}
\hline \multirow{2}{*}{ Nutritional index } & \multicolumn{5}{c|}{ chemical and tested concentration } \\
\cline { 2 - 6 } & Control & \multicolumn{2}{c|}{ Pyriproxyfen } & Abamectin \\
\cline { 2 - 6 } & & $\mathrm{LC}_{50}$ & $\mathrm{LC}_{25}$ & $\mathrm{LC}_{50}$ & $\mathrm{LC}_{25}$ \\
\hline \multirow{2}{*}{ Weight of Ingested food (gr) } & 100.00 & $62.50^{*}$ & $50.00^{*}$ & $50.00^{*}$ & $50.00^{*}$ \\
& \pm 0.003 & \pm 0.004 & \pm 0.003 & \pm 0.001 & \pm 0.002 \\
Weight of unconsumed food (gr) & 100.00 & 108.33 & 101.66 & $256.66^{* *}$ & 93.33 \\
& \pm 0.010 & \pm 0.006 & \pm 0.006 & \pm 0.017 & \pm 0.003 \\
Weight of digested food (gr) & 100.00 & $60.00^{*}$ & 80.00 & $40.00^{* *}$ & 80.00 \\
& \pm 0.003 & $\pm 0 ., 004$ & \pm 0.003 & \pm 0.001 & \pm 0.002 \\
Weight of feaces t (gr) & 100.00 & $63.64^{*}$ & $63.64^{*}$ & $27.27^{* * *}$ & $45.45^{* *}$ \\
& \pm 0.002 & \pm 0.001 & \pm 0.001 & \pm 0.001 & \pm 0.001 \\
ECI & 100.00 & $50.61^{*}$ & $61.02^{*}$ & $17.92^{* * * *}$ & 79.17 \\
& \pm 2.502 & \pm 3.36 & \pm 10.697 & \pm 1.617 & \pm 21.89 \\
ECD & 100.00 & $51.42^{*}$ & $53.55^{*}$ & $13.99^{* * *}$ & $62.86^{*}$ \\
& \pm 4.46 & \pm 1.743 & \pm 7.048 & \pm 2.067 & \pm 1.065 \\
\hline
\end{tabular}

Each value represents the mean of 100 larvae + Std. Dev. Compared to the control value,

$(* * *)$ highly significant $p \leq 0.001,(* *)$ moderately significant $p \leq 0.01$ and $(*)$ significant $p \leq 0.05$ (student $t$-test).

ECI: Efficiency of conversion of ingested food to body matter.

ECD: Efficiency of conversion of digested food to body matter. 
fig (3a): Part of a cross section in the midgut of untreated $3^{\text {th }}$ instar larvae of $S$. littoralis $[10 \mathrm{X}]$.

a) longitudinal muscles

b) circular muscles

c) basement membrane

d) epithelium layer

e) peritrophic membrane

f) lumen
Fig (3b): Cross section in 3 rd instar S.littorallis larvae treated with LC50 pyriproxyfen $[3.2 \mathrm{X}]$.

c) basement membrane [broken up in some areas]

d) epithelium layer [ where the epithelial cells were detached from the basement membrane]

e) peritrophic membrane

g) cell debris

Fig( $3 c$ ): Section in the midgut of 3 rd instar S. litorallis larvae treated with LC50 abamectin [3.2 X].
a) longitudinal muscles
c) basement membrane [appears damaged]
d) epithelium cells are disintegrated
e) peritrophic membrane

Arab Univ. J. Agric. Sci., 14(2), 2006 
a basement membrane. These layers are encircled by the muscular layers (Fig. 3a).

Some histological changes were observed in the midgut sections of larvae; prepared 3 days post treatment with $\mathrm{LC}_{50}$ of pyriproxyfen in their diet. The distal ends of some columnar epithelial cells become somewhat distended with disrupted microvilli, while in other areas the cells remain intact, (Fig. 3b). The peritrophic membrane appears impaired and may be stretched or broken down in some places.

Application of abamectin at $\mathrm{LC}_{50}$ value to the diet of third instar larvae caused a marked higher effect in the midgut of treated larvae (Fig. 3c). The midgut epithelium cells loose their columnar structure, in some areas these cells appear sloughed and the midgut lumen was filled with debris, presumably from degenerating cells. Only remnants of the peritrophic membrane can be detected.

\section{DISCUSSION}

The slow action of pyriproxyfen may be attributed to its long lasting mode of action as juvenile hormone mimics interfere with the hormonal balance at the molting process as mentioned by Dhadialla et al (1998). Meanwhile, the relative rapid action of abamectin may be due to its mode of action as a neurotoxic insecticide which affect the $\gamma$-amino butyric acid (GABA) receptor and block the GABA-gated chloride channel in the affected larval brain (Bloomquist, 1996 and Raymond-Delpech et al 2005). The reduction in ingested, digested and unconsumed food after treatment may be attributed to the effect of the tested chemicals on the activity of invertase, trehalase and other digestive related enzymes as determined by Rizk,( 1998).

The obtained histological changes in the mid-gut of treated larvae are similar to results reported by Mostafa and ElAttal, (1985) in S. littoralis and (Mohammed et al 1993) in Earias insulana. Such effects were reported to be as a result of the tested compounds on stimulation of the cellular differentiation in midgut epithelia and formation of large autophagic vacuoles. In addition it was found that abamectin and pyriproxyfen caused several tissue and cell impairment which was characterized by hypertrophy of the epithelium. Similar results were reported in other insects treated with similar compounds, i.e. fire ant, Solenopsis invicta, cat flea, Ctenocephalides felis, Pectinophora gossypiella, and Earias insulana (Glancey et al 1982; Meola et al 1996 \& 2001)

\section{REFRENCES}

Abbott, W.S. (1925). A method of computing the effectiveness of an insecticide. J. Econ. Entomol. 18: 265-267.

Bloomquist, J.R. (1996). Ion channels as targets for insecticides. Annu. Rev. Entomol. 41: 163-190.

Dhadialla, T.S.; G.R. Carlson and D.P. Le, (1998) New insecticides with ecdysteroidal and juvenile hormone activity. Ann. Rev. Entomol. 43: 545-569.

Farag, A.M.A. (2001). Biochemical Studies on the Effect of Some Insect Growth Regulators on the Cotton Leafworm., pp. 123-124. M.Sc. Thesis, Fac. Agric., Cairo University, Egypt.

Finney, D.J. (1972). Probit Analysis: a Statistical Treatment of the Sigmoid Response Curve. p. 33, Cambridge Univ. Press, U.K. 
Glancey, B.M.; C.S. Lofgren and D.F. Williams (1982) Avermectin B1a: effects on the ovaries of red imported fire ant queens (Hymenoptera: Formicidae). $\boldsymbol{J}$. Med. Entomol. 19: 743-747.

Halley, B.A.; J.A. William; V. Heuvel and P.G. Wislocki (1993). Environmental effects of the usage of avermectines in livestock. Veterinary Parasitology 48: 109-125.

Mcfarlane, J.E. (1985). Nutrition and digestive organs. In: Blum, M.S. (ed). Fundamentals of Insect Physiology. pp. 59-89, Wiley Interscience, New York.

Meola, R.W.; S. Pullen and S. Meola (1996). Toxicity and histopathology of the growth regulator pyriproxyfen to adults and eggs of the cat flea (Siphonaptera : Pulicidae). J. Med. Entomol. 33(4): 670-679.

Meola, R.W.; S.R. Dean and G. Bhaskaran (2001). Effects of juvenile hormone on eggs and adults of the cat flea (Siphonaptera: Pulicidae). J. Med. Entomol. 38(1): 85-92.

Mohammed, I.M.; N.M. Hussein and A.A. Rebia (1993). Effect of Juvenoid Pyriproxyfen in the Gut and Malpighian Tubules of the Spiny Bollworm Earias insulana (Lepidoptera: Noctuidae).. 17: 110-124, Fac. Agric. Al-Azhar Univ., Cairo.
Mostafa, O.R. and A.M. El-Attal (1985). Evaluation of chitin synthesis inhibitor triflumuron against the cotton leafworm Spodoptera littoralis (Boisd.). Bull. Entomol. Soc. Egypt. Econ. Ser. 14: 155-159.

Mostafa, S.A. (1993). Biochemical Effect of Some Chemical Compounds on Spodoptera littoralis (Boisd.), p. 128. Ph.D. Thesis, Fac. Agric. Al-Azhar Univ., Egypt.

Quistad, G.B.; L.E. Staiger and D.A. Schooley (1974). Environmental degradation of the insect growth regulator methoprene [isopropyl (3E, AE)-11methoxy-3, 7, 11-trimethyl-2, 4dodecadienoate]. I. metabolism by alfalfa and rice. J. Agric. Food Chem. 22 (4): 582-589.

Raymond-Delpech, V.; K. Matsuda; B.M. Sattelle; J.J. Rauh and D.B. Sattelle (2005). Ion channels: molecular targets of neuroactive insecticides. Invert. Neurosci., 5(3): 119-133.

Rizk, S.M.T. (1998). Biochemical and Histochemical Studies on Effect of Natural Products on Some Cotton Pests., pp. 32-33. Ph.D. Fac. Agric., Al-Azhar Univ., Cairo.

Waldauer, G.P. (1968). The consumption and utilization of food by insects. Adv. Insect Physiol. 5: 279-288. 
بحلة اتحاد الجامعات العربية للدراسات والبحوث الزراعية ، جامعة عين شمس ، القاهرة ،14(2) ، 803-812 ، 2006 بعض التأثيرات الفسيولوجية والنسيجية المرضية لمبيدان حيويان Spodoptera littoralis (Boisd.) على حشرة دودة ورق القطن

[51]

\author{
لطفى عبد الحميد يوسف 1 \\ 1- قسم وقاية النبات - كلية الزراعة - جامعة عين شمس - شبرا الخيمة - القاهرة - مصر
}

تم تقوي ـم كل م ـن التأثي ــرات وزن البراز اليرقى. أيضاً، فقد أمكن تقدير

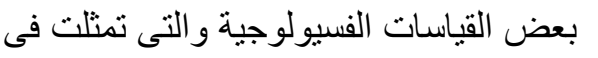

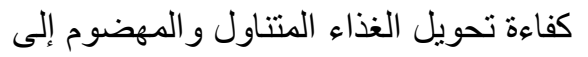

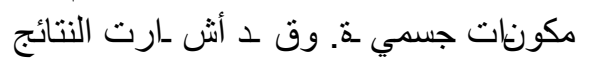

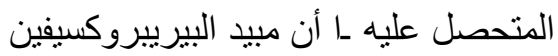

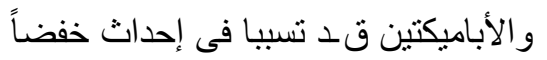

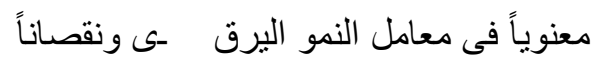

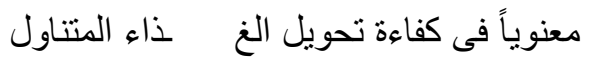

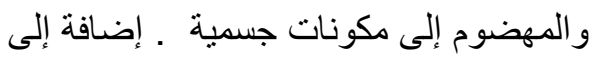
ما سبق، فقد وج ــ أن كلا المبيدان قد تسبيا

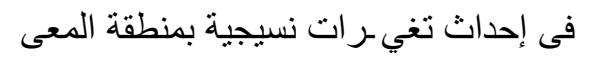

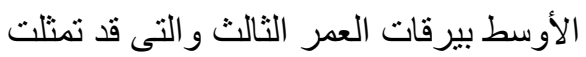

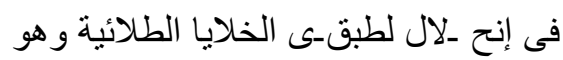

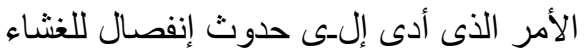
حول الغذائى بالمعى الأوسط.

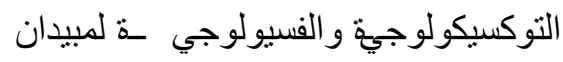
حيويان و هما البيريبرو كسيفين و الأباميكتين

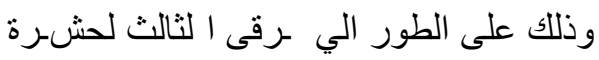

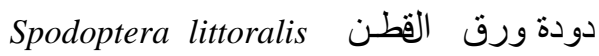
(Boisd.) نتائج سمية هذان المبيدان من قيم التركيزات

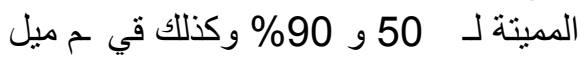
لخطوط السمية ، فق د تبين أن الأباميكتين

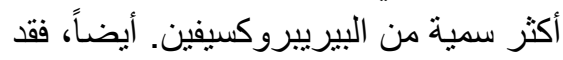

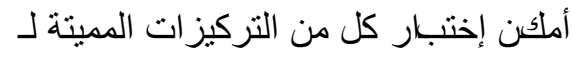

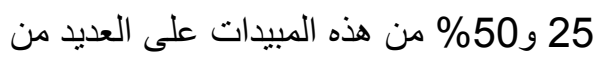

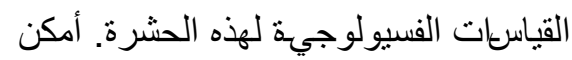

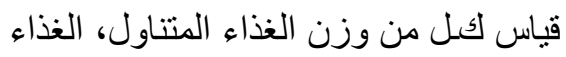
المهضوم، الغذاء غير المتغذى عليه،

تحكيم: أ.د فائزة أحمد مرعى عطى

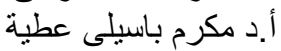

